\title{
PENGOLAHAN ECENG GONDOK (Eichhornia crassipes) UNTUK PENINGKATAN PENDAPATAN MASYARAKAT DAN PELESTARIAN DANAU BUYAN DI DESA PANCASARI KECAMATAN SUKASADA KABUPATEN BULELENG PROPINSI BALI
}

\author{
N.L. Kartini ${ }^{1}$, dan I.G. Suranjaya ${ }^{2}$
}

\begin{abstract}
ABSTRAK
Pengabdian kepada masyarakat ini bertujuan untuk pengolahan Eceng Gondok (Eichhornia Crassipes) untuk Peningkatan Pendapatan Masyarakat dan Pelestarian Danau Buyan. Metode yang diterapkan dalam pemberdayaan masyarakat pada kegiatan KKN PPM adalah sebagai berikut: (1) Kordinasi dan komunikasi secara partisipasif dengan kelompok tani Subak Abian untuk merumuskan program mulai dari perencanaan, operasional dan evaluasi; (2) Penyuluhan untuk membangun persepsi dan pemahaman masyarakat mengenai inovasi atau program yang diterapkan; (3) Pelatihan dan simulasi mengenai terapan ipeks yang dialihkan bagi masyarakat; (4) Pendampingan yaitu pertemuan secara berkala dan berkelanjutan antara pendamping dengan masyarakat sasaran hingga ipteks yang dialihkan dapat dilaksanakan secara mandiri oleh masyarakat. Kegiatan yang dilakukan meliputi (1) Penyuluhan dan koordinasi pada anggota dan pengurus subak Abian Desa Pancasari; (2) Edukasi kepada anak sekolah, petani, dan masyarakat mengenai pelestarian lingkungan danau; (3) Pelatihan dan pembuatan demplot penerapan prosedur operasional baku pertanian ramah lingkungan; (4) Pelatihan alih teknologi fermentasi dalam pembuatan pupuk organik dan pakan ternak dari enceng gondok; (5) Pelatihan alih teknologi pengolahan enceng gondok menjadi sumber energi (biogas); dan (6) Edukasi bagi anak sekolah dalam pelestarian danau dan kesehatan lingkungan.
\end{abstract}

Kata Kunci : pengolahan, enceng gondok (Eichhornia Crassipes), pendapatan masyarakat, pelestarian danau

\begin{abstract}
The community services is aimed at the processing of Eceng Gondok (Eichhornia Crassipes) for Increasing Community Revenue and Buyan Lake Conservation. The methods applied in the community empowerment of KKN PPM activities are as follows: (1) Participatory coordination and communication with Subak Abian farmer groups to formulate programs ranging from planning, operation and evaluation; (2) Counseling to build community perceptions and understanding of innovations or programs implemented; (3) Training and simulation of applied ipeks transferred to the community; (4) Assistance is regular and continuous meetings between assistants with target communities to transferred science and technology can be implemented independently by the community. Activities undertaken include (1) Counseling and coordination of members and administrators of Subak Abian Desa Pancasari; (2) Education to schoolchildren, farmers and the community regarding the preservation of the lake environment; (3) Training and manufacture of demonstration plots of standard operating procedures for environmentally friendly agriculture; (4) Training on transfer of fermentation technology in the manufacture of organic fertilizer and animal feed from water hyacinth.
\end{abstract}

Keywords : processing, water hyacinth (Eichhornia Crassipes), community income, lake conservation

${ }^{1}$ Staf Pengajar Fakultas Pertanian Universitas Udayana, luhkartini2017@gmail.com

${ }^{2}$ Staf Pengajar Fakultas Peternakan Universitas Udayana 


\section{PENDAHULUAN}

Danau Buyan merupakan danau yang sangat terkenal di Bali. Danau Buyan terletak tepat di lereng gunung Buyan. Danau Buyan ini sendiri merupakan danau terluas yang ada di bali, Letak danau ini terdapat pada ketinggian 1.050 diatas permukaan air laut. Air danau ini sangat alami karena berasal dari air hujan dan rembesan air dari hutan yang ada di pegunungan. Luas permukaan danau ini sekitar 16 Kilometer persegi dengan kedalaman berfariasi berrata-rata kedalaman 50,8 meter

Danau Buyan yang merupakan sumber air dari sebagian besar sungai di kabupaten Buleleng pada 10 tahun terakhir mengalami masalah lingkungan yang serius. Masalah utama adalah pertumbuhan enceng gondok dan berbagai jenis gulma lainnya yang berimplikasi kepada pendangkalan dan berkurangnya keindahan danau. Tumbuhan gulma yang menutupi permukaan danau tersebut sudah mencapai delapan hektare lebih. Atau hampir lima belas hingga dua puluh persen, luas danau mengalami pengurangan akibat tumbuhnya gulma. Semakin banyaknya eceng gondok tumbuh di atas danau ini membuat air di danau semakin cepat menguap, begitu pula dengan keasrian danau semakin terancam

Pertumbuhan enceng gondok dan gulma lain yang semakin luas tidak terlepas dari aktivitas pertanian yang dilakukan di sekitar danau. Pertanian sayuran yang mengaplikasikan pupuk kimia sintetik terutama nitrogen dan super fospat dalam dosis tinggi telah mendorong jumlah limbah senyawa tersebut ke dalam danau yang semakin meningkat pula. Kondisi tersebut menimbulkan gejala yang disebut euterofikasi yang memicu tumbuhnya enceng gondok dan gulma lain serta dapat menurunkan kualitas air danau secara signifikan.

Kondisi di atas menuntut adanya solusi yang holistik untuk menekan populasi enceng gondok di danau Buyan, baik secara preventif maupun aksi penanggulangan. Upaya preventif misalnya dengan mengurangi limbah nitrogen dan fospat dari aktivitas pertanian, sedangkan aksi penanggulangan dapat dilakukan dengan pengolahan enceng gondok menjadi pupuk organik. Pupuk organik hasil pengolahan enceng gondok dapat dijadikan sebagai sumber pupuk bagi pertenian sayuran di sekitar danau. Selain itu, enceng gondok juga dapat diolah menjadi kerajinan tangan seperti anyaman dompet, tas, tempat tissue yang dapat sebagai cindera mata bagi wisatawan yang berkunjung ke kawasan tersebut. Persoalan yang dihadapi adalah teknologi sistem pertanian yang ramah lingkungan dengan mengutamakan input organik serta teknik mengolah enceng gondok menjadi pupuk dan keterajinan belum dikuasai oleh masyarakat di sekitar danau. Untuk tujuan tersebut, maka sangat diperlukan adanya regulasi dan pemberdayaan masyarakat melalui pendampingan Perguruan Tinggi. Pendampingan dilakukan dengan melibatkan mahasiswa sebagai agen utama dibawah kordinasi dosen pembimbing lapangan. Dalam konteks ini, kegiatan pendampingan akan dilakukan melalui program Kuliah Kerja Nyata Pemberdayaan Masyarakat (KKN-PPM).

\section{METODE PELAKSANAAN}

Metode yang diterapkan dalam pemberdayaan masyarakat pada kegiatan KKN PPM adalah sebagai berikut: (1) Kordinasi dan komunikasi secara partisipasif dengan kelompok tani masyarakat untuk merumuskan program mulai dari perencanaan, operasional dan evaluasi; (2) Penyuluhan untuk membangun persepsi dan pemahaman masyarakat mengenai inovasi atau program yang diterapkan;

\section{7 | BULETIN UDAYANA MENGABDI}


(3) Pelatihan dan simulasi mengenai terapan ipeks yang dialihkan bagi masyarakat; (4) Pendampingan yaitu pertemuan secara berkala dan berkelanjutan antara pendamping dengan masyarakat sasaran hingga ipteks yang dialihkan dapat dilaksanakan secara mandiri oleh masyarakat.

\section{HASIL DAN PEMBAHASAN}

a. Pelatihan Pembuatan Mikro Organisme Lokal (MOL) dan Vermikompos dari Enceng Gondok

Kegiatan pembuatan Mikro Organisme Lokal (MOL) dan Vermikompos dari Enceng Gondok dilakukan pada tanggal 21 juli 2017. Pihak yang terlibat terdiri dari 60 petani dari kelompok nelayan Danau Buyan, mahasiswa KKN, dan Balai pelestarian danau Wilayah Bali Nusra.

Bentuk kegiatan berupa pelatihan cara membuat mol dari enceng gondok dan vermikompos dari enceng gondok, dan membuat balai pengolahan vermikompos berukuran 4 × 6 meter , bertiang beton dengan atap asbes dan dinding batako. Pada kegiatan ini juga dilepaskan sebanyak $10 \mathrm{~kg}$ bibit cacing.

b. Kegiatan pengolahan pupuk organik Eceng Gondok padat dan cair melalui teknologi fermentasi

Selain memiliki dampak yang merugikan eceng gondok juga dapat dimanfaatkan sebagai bahan baku dalam pembuatan pupuk organik baik bentuk padat maupun cair. Kegiatan ini diawali dengan penyuluhan pengembangan pertanian ramah lingkungan yang dilakukan pada tanggal 20 Agustus 2017 bertempat di Wantilan Pura Ulun Danu Buyan. Penyuluhan dan Pelatihan diberikan oleh pendamping dari Tim IbW-Unud dan dihadiri oleh sebanyak 20 orang petani anggota kelompok tani "Sari Sedana" dan anggota Gapoktan desa Pancasari dengan ketua Bapak Gede Darmada. Materi penyuluhan dan pelatihan adalah tentang pengembangan pertanian ramah lingkungan melalui pengolahan eceng gondok menjadi pupuk organik padat dan cair.

Memberikan pelatihan tentang cara-cara pengolahan eceng gondok menjadi pupuk organik padat dan cair serta cara pengemasan (packing) agar dihasilkan pupuk organik yang baik dan mencukupi jumlahnya sehingga ketersediaannya dapat mengurangi biaya produksi, mengurangi penggunaan pupuk kimia dalam upaya menunjang sistem pertanian ramah lingkungan. Penyuluhan serta pelatihan berjalan lancar dan masyarakat sasaran yaitu para petani anggota Kelompok Tani "Sari Sedana" dapat memahaminya mengapa eceng gondok itu perlu diolah menjadi pupuk organik padat atau cair. Hal ini disebabkan karena mereka belum mampu memanfaatkan potensi tanaman eceng gondok secara maksimal, mereka belum menerapkan sistem produksi dan manajemen usaha dalam pengolahan eceng gondok menjadi pupuk organik padat maupun cair dan mereka belum terbiasa melakukan aplikasi pupuk organik sebagai pupuk dasar pada lahan pertanian ataupun perkebunannya.

Dalam kegiatan ini dilakukan pendampingan melalui transfer teknologi dalam pengolahan eceng gondok menjadi pupuk organik padat dan cair guna mendukung pengembangan sistem pertanian hortikultura ramah lingkungan dan penurunan biaya produksi serta ikut berkontribusi dalam upaya menjaga kelestarian wilayah perairan danau Buyan. Manfaat kegiatan ini bagi kelompok mitra 
adalah : 1) meningkatkan usaha produksi pupuk organik padat dari eceng gondok, 2) meningkatkan usaha produksi pupuk cair eceng gondok, 3) meningkatkan aplikasi pupuk organik sebagai pupuk dasar dan 4) ikut menjaga kelestarian wilayah perairan danau Buyan.

c. Pelatihan dan Demoplot Pertanian ramah lingkungan

Kegiatan dilakukan pada tanggal 20 agustus 2017 diikuti oleh Gapoktan Desa Pancasari. Bentuk kegiatan berupa penyuluhan tentang pertanian ramah lingkungan, pelatihan pemupukan dan penggunaan biopestisida, serta pembuatan demplot SOP aplikasi pertanian sayuran ramah lingkungan

d. Edukasi Pelestarian danau dan lingkungan kepada anak-anak sekolah

Kegiatan anak sekolah cinta danau dilakukan pada tanggal 10, 11 dan 17 agustus 2017, melibatkan. Bentuk kegiatan berupa penanaman rasa cinta lingkungan, pengumpulan sampah dan pemilahan sampah plastik dan organik, serta pembersihan danau. Pihak yang terlibat murid-murid sekolah dasar di Desa Pancasari, para guru dan mahasiswa KKN PPM.

\section{KESIMPULAN DAN SARAN}

Memperhatikan pelaksanaan dan hasil kegiatan KKN PPM, dapat disimpulkan sebagai berikut; 1) KKN PPM tematik pengolahan enceng gondok dan pelestarian danau Buyan dapat meningkatkan empati mahasiswa terhadap persoalan lingkungan dan kemasyarakatan sekaligus mengajarkan mahasiswa hidup bermasyarakat; 2) Program yang telah berhasil dilaksanakan diantaranya : pembuatan MOL dan vermikompos dari enceng gondok, Aplikasi teknologi fermentasi untuk pengolahan enceng gondok menjadi pupuk organik berkualitas, edukasi cinta lingkungan dan pelestarian danau; 3) KKN PPM mendapatkan sambutan dan dukungan yang sangat baik dari masyarakat terbukti dari besarnya paritipasi masyarakat dalam pelaksanaan kegiatan KKNPPM.

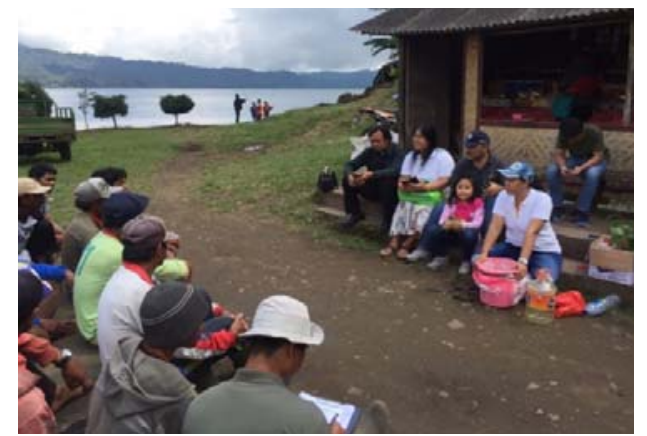

Gambar 1. Pelatihan pembuatan MOL

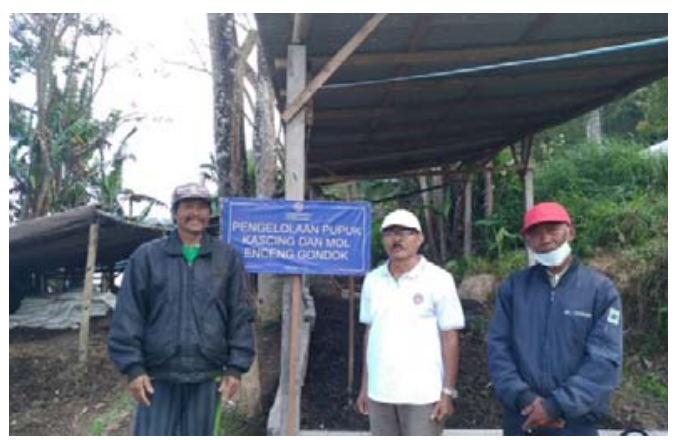

Gambar 2. Rumah pengolahan Vermikompos 


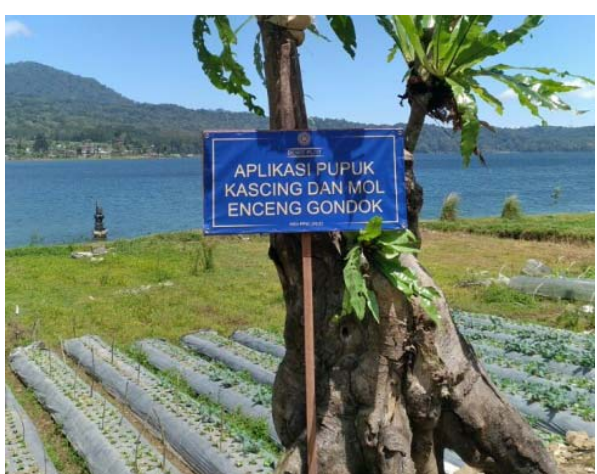

Gambar 3. Demoplot Pertanian Organik

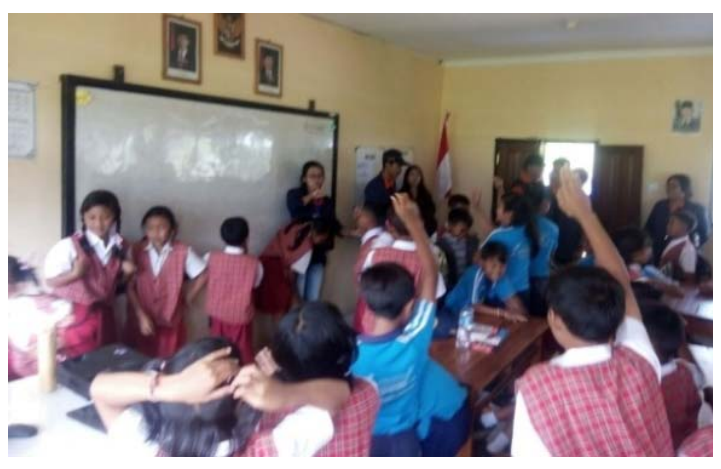

Gambar 4. Edukasi tentang kelestarian danau

\section{UCAPAN TERIMA KASIH}

Penulis mengucapkan terima kasih kepada KEMENRISTEK DIKTI atas dana yang diberikan lewat program KKNPPM, Rektor Universitas Udayana, Ketua LPPM beserta staf terima kasih atas tenaga yang diberikan dalam pelaksanaan di lapangan, sehingga pengabdian kepada masyarakat terlaksana sesuai rencana.

\section{DAFTAR PUSTAKA}

Badan Statistik Propinsi bali. 2015. Bali dalam Angka.

Assosiation of Official Analytical Chemist (A.O.A.C.). 1990. Official Method of Analysis. $13^{\text {th }}$ Ed., Washington, DC.

Euthalia Hanggari Sittadewi. 2007. Pengolahan Bahan Organik Eceng Gondok Menjadi Media Tumbuh Untuk Mendukung Pertanian Organik. J.Tek.Ling. 8:(3):229-234.

Anastasia R. Moia*, Dingse Pandiangana, Parluhutan Siahaana, Agustina M Tangapoa. Pengujian Pupuk Organik Cair dari Eceng Gondok (Eichhornia crassipes)Terhadap Pertumbuhan Tanaman Sawi (Brassica juncea). JURNAL MIPA UNSRAT ONLINE 4 (1) 15-19. 